\title{
ELECTROMAGNETIC EXPOSURE EFFECT ON MICROBIOLOGICAL CHARACTERISTICS OF RAW MILK
}

\author{
Tatiana Ananeva ${ }^{1}$, Vera Ostroukhova ${ }^{1}$, Elena Vasilyeva ${ }^{2}$ \\ ${ }^{1}$ Russian State Agrarian University - Moscow Timiryazev Agricultural Academy, Russia; \\ ${ }^{2}$ Nizhegorod State Engineering and Economic University, Russia \\ anatanya@list.ru,vostroukhova@bk.ru,vea717@mail.ru
}

\begin{abstract}
The increase of the sanitary and hygienic qualities of milk and dairy products demands working professionally on manufacturing technology and culture, improvement of equipment exploitation conditions and development of methods of influence on microbiological characteristics. A method of electromagnetic influence on the control system of a microbial cell is proposed, which allows to reduce the degree of microorganisms development and improve the quality of milk, and, therefore, extend the expiration date of products. The object of the study was the milk of cows of the Kholmogory breed, which were kept using loose (group I) and tied (group II) housing system. It has been established that the method of keeping does not affect the physicochemical parameters, which meet the requirements for raw milk. The density, freezing point, acidity and somatic cells count were affected by the season. Changes in the quantitative composition of the sanitary-indicative microorganisms of raw milk depend both on the way the cows are kept and milked, and on the season. The highest bacterial contamination of milk was obtained for loose housing. The maximum quantity of microorganisms is observed in the summer for both methods of keeping. Salmonella were absent. Yeasts and molds are registered in all milk samples. The influence of electromagnetic radiation on the development of individual microorganisms is registered. The largest quantity of mesophilic aerobic and facultative anaerobic microorganisms (QMAFAnM) was in raw milk without external influences with total number $486000 \mathrm{CFU} \cdot \mathrm{ml}^{-1}$. When exposed to electromagnetic pulses, the quantity of yeast and mold fungi decreased 9 or more times.
\end{abstract}

Keywords: milk, dairy products, quality, safety, electromagnetic tool.

\section{Introduction}

Milk is a complex food product, which contains almost all nutrients essential to human health in an easy-digestible and well-balanced form. It is not surprising that for most of countries worldwide the dairy breeding is the leading branch in the agricultural sector, the consumption of milk and dairy products increases each year and the variety of products made from milk widens.

Failure to comply with the parameters of the technology of milk production, the conditions of processing and storage leads to the accumulation of microorganisms and their products of vital functions, which can cause food poisoning among consumers. In this regard, the assessment of the bacterial load level, as one of the objective indicators of the sanitary status and technological properties of milk, is an obligatory measure of raw milk materials manufacturing quality control $[1 ; 2]$.

Among the variety of traditional methods of raw milk primary processing, a new direction in the innovative technologies development that improves the quality and safety factors of milk should be highlighted [3-6].

The aim of this research was to develop a method for controlling the development of microorganisms in the raw milk obtained under different technological conditions to improve the physico-chemical and microbiological parameters of milk.

\section{Materials and methods}

The research was carried out on the cattle stock of Kholmogory breed at ZAO PZ "Zelenogradskoye" Moscow Region and Testing laboratory of milk quality estimation of the Russian State Agrarian University - Moscow Timiryazev Agricultural Academy.

For the experiment, two groups of the Kholmogory breed cows having the second and third lactations were formed. The group I contained animals with loose housing, milking was carried out at the herringbone milk parlor "Yolochka 12x2" of brand WestfaliaSurge; the group II of cows was kept tied, milking was carried out on the ADM-8A plant.

Milk yields from each cow were determined by the results of control milking (once a month). Selection and preparation of milk samples for physical and chemical studies were carried out in accordance with the requirements of GOST 13928-84. In individual milk samples, the content of dry matter $(\%)$, fat $(\%)$, protein $(\%)$, lactose $(\%)$ was measured once a month using the Bentley 2000 
device and the somatic cell count was calculated using the Somacount 300 device. Acidity $\left({ }^{\circ} \mathrm{T}\right)$, density $\left({ }^{\circ} \mathrm{A}\right)$ and the thermostability (\%) of milk were determined in accordance with generally accepted procedures [7].

Sanitary and hygienic indicators of raw milk were estimated once in a season (winter, spring, summer, autumn) with threefold repetition. Microbiological studies were conducted no later than 2 hours after sampling. Studies to determine the sanitary quality of raw aggregated milk were carried out according to the requirements of the referee method. To determine the presence of a residual amount of antibiotics in the milk, a method based on the ability of antibiotics to inhibit the growth of microorganisms sensitive to them was used $[1 ; 2 ; 8]$.

To study the effect of electromagnetic pulses on the quality factors of milk and dairy products, we used a device equipped with a current pulse generator with a control panel regulating the duration of pulses and pauses and the output voltage of the pulse, structurally connected with the milk tank. An electromagnetic device with the following parameters of electric current was used: the pulse duration was $19.82 \mathrm{~ms}$, the pause duration was $19.64 \mathrm{~ms}$, the pulse voltage was $22 \mathrm{~V}$, the processing time was 20 minutes (first option). The other option was milk without exposure to electromagnetic radiation (control sample of the experiment).

\section{Results and discussion}

Based on the research results it was established that the milk productivity of the cows of group I exceeds the productivity of the cows of group II by $353 \mathrm{~kg}$, which is reflected in Table 1.

Table 1

\section{Milk production of the cows}

\begin{tabular}{c|c|c|c|}
\hline Factor & Group I & Group II \\
\hline Milk yield, $\mathrm{kg}$ & $7460.1 \pm 97.69 *$ & $7107.2 \pm 106.85$ \\
\hline Fat, \% & $4.34 \pm 0.03$ & $4.33 \pm 0.04$ \\
\hline Protein, \% & $3.26 \pm 0.01 *$ & $3.21 \pm 0.01$ \\
\hline & 93.30 & 95.13 \\
\hline Lactation stability coefficient, \% & $9 \leq 0.05 * *-P \leq 0.01 * * * P 1 \leq 0.001$ &
\end{tabular}

The data of Table 1 show that the cows of both groups are characterized by high indicators of the milk productivity level. The milk yield of the 1st group cows exceeds the similar index of the cows from group II by $352.9 \mathrm{~kg}$ with statistical significance. Cows of the Kholmogory breed usually have high level of milk protein, which is confirmed by the data obtained. However, in milk of cows with a loose housing, the amount of protein was $0.05 \%(\mathrm{P} \leq 0.05)$ higher. The cows of group II with tied housing have higher value of the lactation stability coefficient. This coefficient for animals of this group was $1.8 \%$ higher relative to the group I cows that were kept loose, which is probably due to a large variation in the data.

Milk, as a food and raw material for dairy enterprises, is of value only, if it has high quality indicators (Table 2).

Quality factors of cow milk according to the season of the year

Table 2

\begin{tabular}{|c|c|c|c|c|c|}
\hline Season & Animal Group & Fat, \% & Protein, \% & Lactose, \% & Dry matter, \% \\
\hline \multirow{2}{*}{ Winter } & Group I & $4.49 \pm 0.22$ & $3.25 \pm 0.08$ & $4.58 \pm 0.06$ & $13.41 \pm 0.54$ \\
\cline { 2 - 6 } & Group II & $4.47 \pm 0.4$ & $3.25 \pm 0.03$ & $4.44 \pm 0.16$ & $13.09 \pm 0.14$ \\
\hline \multirow{2}{*}{ Spring } & Group I & $4.51 \pm 0.11$ & $3.34 \pm 0.01$ & $4.70 \pm 0.12$ & $13.50 \pm 0.10$ \\
\cline { 2 - 6 } & Group II & $4.51 \pm 0.09$ & $3.31 \pm 0.12$ & $4.53 \pm 0.04$ & $13.16 \pm 0.15$ \\
\hline \multirow{2}{*}{ Summer } & Group I & $4.49 \pm 0.21$ & $3.22 \pm 0.09$ & $4.52 \pm 0.03$ & $13.34 \pm 0.32$ \\
\cline { 2 - 6 } & Group II & $4.44 \pm 0.12$ & $3.21 \pm 0.04$ & $4.48 \pm 0.11$ & $12.92 \pm 0.08$ \\
\hline \multirow{2}{*}{ Autumn } & Group I & $4.59 \pm 0.40$ & $3.30 \pm 0.17$ & $4.59 \pm 0.04$ & $13.54 \pm .050$ \\
\cline { 2 - 6 } & Group II & $4.50 \pm 0.13$ & $3.28 \pm 0.01$ & $4.52 \pm 0.10$ & $13.18 \pm 0.06$ \\
\hline
\end{tabular}


Analyzing the obtained data on the chemical composition of cow milk (Table 2), it can be said that in the milk of cows with loose housing, the dry matter content is on average $0.36 \%$ higher than for animals with tied housing. It should be noted that the greatest difference was observed in the summer period $(0.42 \%)$, and the smallest - in winter $(0.32 \%)$.

It was found that the animals of group I (loose housing) outnumber the cows kept tied, in terms of fat, protein and lactose in milk, regardless of the season. However, the discovered difference is not statistically significant.

The density of milk depends on its chemical composition, in particular on the fat content. According to this indicator, the naturalness of the product is judged. The density of natural milk varies in the range of $27-33^{\circ} \mathrm{A}$.

Analyzing the dynamics of milk density according to the seasons of the year, it can be said that in group II during the year the density index was lower than for the cows of group I. Upon that the greatest difference is observed in the autumn period (October-November) and it was rather small. A decrease in the milk density in both groups of animals by the beginning of the summer period and the further growth with the attainment of maximum values in winter was noted.

The results of the conducted research suggest that the indicators of the chemical composition and density of milk are not significantly affected by the way the cows are kept and the season of the year. This is due to the fact that the farm uses year-round stall maintenance of cows with the same type of feeding.

The experiments show that the milk of the cows of both groups is characterized by good physicochemical parameters (Table 3) and meets the requirements for milk as a raw material for the production of dairy products.

Table 3

Physico-chemical parameters of cow milk according to the season

\begin{tabular}{|c|l|c|c|c|c|c|c|}
\hline \multirow{2}{*}{ Season } & \multirow{2}{*}{ Month } & \multicolumn{2}{|c|}{ Freezing point, ${ }^{\circ} \mathrm{C}$} & \multicolumn{2}{c|}{ Thermostability, \% } & \multicolumn{2}{c|}{ Acidity, ${ }^{\circ} \mathrm{T}$} \\
\cline { 3 - 8 } & & Group I & Group II & Group I & Group II & Group I & Group II \\
\hline \multirow{3}{*}{ Winter } & December & -0.545 & -0.544 & 72 & 72 & 16.80 & 16.65 \\
\cline { 2 - 8 } & January & -0.540 & -0.539 & 72 & 72 & 16.74 & 16.67 \\
\cline { 2 - 8 } & February & -0.539 & -0.537 & 73 & 72 & 16.78 & 16.61 \\
\hline \multirow{3}{*}{ Spring } & March & -0.538 & -0.537 & 74 & 74 & 16.74 & 16.61 \\
\cline { 2 - 8 } & April & -0.537 & -0.535 & 75 & 75 & 16.72 & 16.60 \\
\cline { 2 - 8 } & May & -0.535 & -0.535 & 75 & 75 & 16.69 & 16.58 \\
\hline \multirow{3}{*}{ Autumer } & June & -0.535 & -0.533 & 74 & 74 & 16.65 & 16.55 \\
\cline { 2 - 8 } & July & -0.537 & -0.531 & 74 & 74 & 16.67 & 16.59 \\
\cline { 2 - 8 } & August & -0.538 & -0.537 & 75 & 75 & 16.70 & 16.60 \\
\cline { 2 - 8 } & September & -0.540 & -0.539 & 75 & 75 & 16.71 & 16.61 \\
\cline { 2 - 8 } & October & -0.543 & -0.540 & 75 & 74 & 16.74 & 16.65 \\
\cline { 2 - 8 } & November & -0.544 & -0.540 & 74 & 72 & 16.77 & 16.64 \\
\hline
\end{tabular}

The freezing point is the temperature at which milk turns into a solid state. This parameter depends on the content of soluble constituents of milk: lactose and mineral salts. The dependence of the freezing point on the concentration of soluble milk substances makes it possible to detect its falsification. The freezing temperature of the collected milk ranged from -0.533 to $-0.545^{\circ} \mathrm{C}$, which excludes falsification.

In February, October and November, there were differences in the thermostability value of milk in the groups of cows with different methods of keeping. In general, during the year, in both groups there was an improvement in the thermostability of milk from the middle of spring to the middle of autumn with a peak in April-May, August-October, followed by a deterioration in December-January. Thermostability has a rather complex nature, mainly determined by the salt balance, the size and chemical composition of the casein molecules. The main reasons for the low value of the parameter are the disturbed salt balance, the protein composition and the excessive acidity of milk, which does not exclude errors in the cows feeding. 
The acidity of fresh milk is $16-18^{\circ} \mathrm{T}$. It is caused by acid salts $\left(9-13^{\circ} \mathrm{T}\right)$, milk proteins $\left(4-6^{\circ} \mathrm{T}\right)$, carbon acid and other acids (1-3 $\left.{ }^{\circ} \mathrm{T}\right)$. Titratable acidity of milk characterizes the freshness of the product. According to the research results, the factor of the titratable acidity of milk depends on the season of the year. It was noted that in winter the milk acidity is higher $\left(16.78-16.80^{\circ} \mathrm{T}\right)$ than in summer $\left(16.65-16.67^{\circ} \mathrm{T}\right)$. At the same time, regardless of the season, the lower acidity of milk was registered for the cows of group II (tied housing). A slight decrease in the acidity of milk could be caused by an increase in the somatic cells count.

During the observation period, the physico-chemical parameters were in accordance with the requirements of the Technical Regulations of the CU "On Safety of Milk and Dairy Products" (TR TS 033/2013), and the differences between the values of the freezing point, thermostability and acidity were insignificant for the cows of groups I and II [2].

The somatic cell count is a complex criterion of milk safety and quality. On the one hand, the excessive somatic cell count in raw materials influences the safety of dairy products due to the development of pathogenic microorganisms (staphylococci, streptococci, CGB, etc.), on the other hand, it also affects the technological qualities of the manufactured products due to a decrease in physico-chemical parameters. The somatic cell count in the milk of cows from group II exceeded the similar index for the cow milk of group I (Fig. 1). During the year, the maximum value was noted in the summer period (July-August) for cows with tied housing - 287-280 th. per $\mathrm{cm}^{3}$.

Analysis of the data in the diagram (Figure 1) shows that the high concentration of somatic cells in the milk of cows of group II (263 th. in $1 \mathrm{ml}$ ) with the tied housing is not critical, but significantly exceeds $(P \leq 0.05)$ this indicator of the cows from group I. The content of somatic cells in the milk of cows of both experimental groups fits the requirements of the Technical Regulations of the CU "On Food Safety" (TR TS 021/2011) [1].

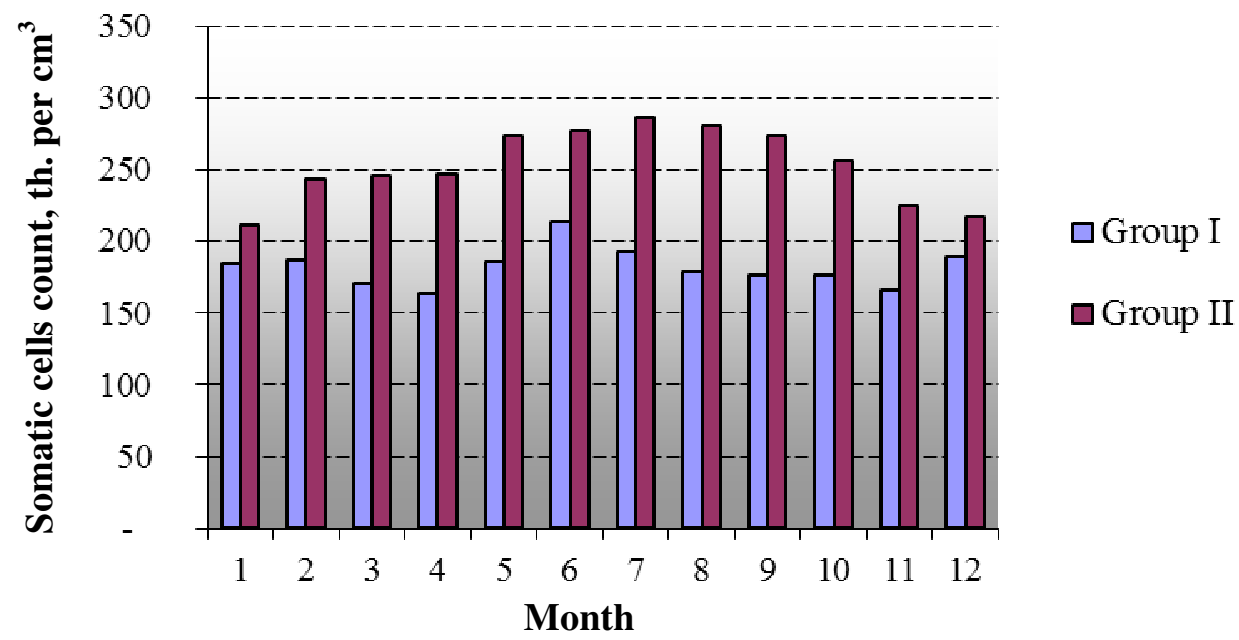

Fig. 1. Somatic cell count according to season

Among the basic microflora of raw milk, which can worsen the quality and safety parameters of dairy products, the following are distinguished: spoilage microorganisms (yeast and mould), pathogenic (salmonella) and sanitary-indicative (QMAFAnM - quantity of mesophilic aerobic and facultative anaerobic microorganisms, CGB - coliform group of bacteria). Changes in the quantitative composition of the sanitary-indicative microorganisms of raw milk, depending on the method of keeping and milking, and also depending on the season, are given in Tables 4-7.

In winter, for loose housing cows (group I), the total quantity of microorganisms (QMAFAnM) was lower than for those with tied housing (Table 4). In the milk of the first test group cows, fewer bacteria of the colibacillus group (CGB) were detected. Salmonella in the milk of the cows of both experimental groups were absent. Yeast and mold fungi are noted in all samples of milk. Yeast in milk of cows kept loose was $120 \mathrm{CFU} \cdot \mathrm{cm}^{-3}$, for cows kept tied $-200 \mathrm{CFU} \cdot \mathrm{cm}^{-3}$; mold fungi count was 76 and $89 \mathrm{CFU} \cdot \mathrm{cm}^{-3}$, respectively. 
Microorganism count in milk during the winter period

Table 4

$*-P \leq 0.05 * *-P \leq 0.01 * * *-P 1 \leq 0.001$

In the spring period the number of basic species of sanitary-indicative microorganisms in the milk of the cows of group I was significantly lower than in the case of the cows of group II. In the samples of milk from both experimental groups of animals, salmonella were not detected (Table 5), which indicates a high level of veterinary and sanitary control of the production process on the farm.

Microorganism count in milk during the spring period

Table 5

\begin{tabular}{|c|c|c|}
\hline Parameter & Group I & Group II \\
\hline QMAFAnM, CFU $\cdot \mathrm{cm}^{-3}$ & $43588 \pm 5099$ & $88127 \pm 8594 * * *$ \\
\hline $\mathrm{CGB}, \mathrm{CFU} \cdot \mathrm{cm}^{-3}$ & $627 \pm 55$ & $3322 \pm 308 * * *$ \\
\hline Salmonella, CFU. $\mathrm{cm}^{-3}$ & Absent & Absent \\
\hline Yeast, CFU. $\mathrm{cm}^{-3}$ & $261 \pm 21$ & $283 \pm 23$ \\
\hline Mould, $\mathrm{CFU} \cdot \mathrm{cm}^{-3}$ & $19 \pm 2$ & $170 \pm 15 * * *$ \\
\hline
\end{tabular}

The data in Table 6 indicate that the highest microorganism count is observed in summer in both groups of cows. The maximum value of the bacterial contamination parameter of milk was found in the second group of cows with tied housing (QMAFAnM - $486289 \mathrm{CFU} \cdot \mathrm{cm}^{-3}, \mathrm{CGB}-6415 \mathrm{CFU} \cdot \mathrm{cm}^{-}$ ${ }^{3}$ and moulds $-200 \mathrm{CFU} \cdot \mathrm{cm}^{-3}$ ). Pathogenic microorganisms, including salmonella, were not found.

Microorganism count in milk during the summer period

Table 6

Microorganism count in milk during the summer period
\begin{tabular}{|c|c|c|}
\hline Parameter & Group I & Group II \\
\hline QMAFAnM, CFU $\cdot \mathrm{cm}^{-3}$ & $117168 \pm 14231$ & $486289 \pm 63217 * * *$ \\
\hline CGB, CFU $\cdot \mathrm{cm}^{-3}$ & $1378 \pm 113$ & $6415 \pm 554 * * *$ \\
\hline Salmonella, CFU $\cdot \mathrm{cm}^{-3}$ & Absent & Absent \\
\hline Yeast, CFU $\cdot \mathrm{cm}^{-3}$ & $704 \pm 54$ & $1000 \pm 71 * * *$ \\
\hline Mould, CFU $\cdot \mathrm{cm}^{-3}$ & $129 \pm 12$ & $200 \pm 17 * * *$ \\
\hline
\end{tabular}

$*-P \leq 0.05 * *-P \leq 0.01 * * *-P 1 \leq 0.001$

The increase in the microorganism count in the investigated samples of milk during the summer period could be caused by the climatic and temperature conditions favorable effect on their growth and development.

In the autumn period (Table 7), for all parameters the microorganism count in the milk of the cows of both groups decreased in comparison with the summer period.

The content of microorganisms in the investigated raw milk did not exceed the permissible requirements stated by the Technical Regulations of the CU "On Safety of Milk and Dairy Products" (TR TS 033/2013) during the whole observation period, and in accordance with the requirements of the Technical Regulations of the CU "On Food Safety" (TR TS 021/2011), milk was assigned to the highest grade. The maximum value of QMAFAnM in the milk samples from cows of both groups did not exceed the permissible value $1 \times 10^{5} \mathrm{CFU} \cdot \mathrm{cm}^{-3}$; there were no pathogenic microorganisms, including salmonella, and the somatic cell count did not reach $2 \times 10^{5}$ cells per $\mathrm{cm}^{3}[1 ; 2]$. 
Microorganism count in milk during the autumn period

Table 7

$*-P \leq 0.05 * *-P \leq 0.01 * * *-P 1 \leq 0.001$

To refine the sanitary and hygienic quality of milk and dairy products, it is necessary to improve the methods of processing raw materials that affect microbiological factors. To solve this problem, a generator of electro-magnetic pulses was applied. The results of the research determining the level of the electromagnetic pulses impact on the microbiological composition of the milk, collected in the summer period, are presented in Table 8 . These are the results for both experimental groups. The exposure time was 30 seconds, the pulse duration was $7.6 \mathrm{~ms}$ and the pause length was $7.6 \mathrm{~ms}$.

Table 8

Results of microorganism development in milk with and without electromagnetic impulse treatment

\begin{tabular}{|c|c|c|c|c|}
\hline \multirow{2}{*}{ Parameter } & \multicolumn{2}{|c|}{ Group I } & \multicolumn{2}{|c|}{ Group II } \\
\hline & Without treatment & With treatment & Without treatment & With treatment \\
\hline $\begin{array}{l}\text { QMAFAnM, } \\
\text { CFU } \cdot \mathrm{cm}^{-3}\end{array}$ & $\begin{array}{l}117168 \pm \\
14231 * * *\end{array}$ & $43300 \pm 5350$ & $\begin{array}{l}486289 \pm \\
63217^{* * *}\end{array}$ & $180300 \pm 20314$ \\
\hline $\begin{array}{c}\text { CGB, } \\
\mathrm{CFU} \cdot \mathrm{cm}^{-3}\end{array}$ & $1378 \pm 113$ & No growth & $6415 \pm 554$ & No growth \\
\hline $\begin{array}{l}\text { Salmonella, } \\
\text { CFU } \cdot \mathrm{cm}^{-3}\end{array}$ & $704 \pm 54 * * *$ & $76 \pm 7$ & $1000 \pm 71 * * *$ & $109 \pm 10$ \\
\hline $\begin{array}{l}\text { Yeast, } \\
\text { CFU } \cdot \mathrm{cm}^{-3}\end{array}$ & $129 \pm 12 * * *$ & $14 \pm 2$ & $200 \pm 17 * * *$ & $20 \pm 3$ \\
\hline
\end{tabular}

From the data in Table 8 , it can be seen that the greatest quantity of mesophilic aerobic and facultative anaerobic microorganisms (QMAFAnM) - $486289 \mathrm{CFU} \cdot \mathrm{cm}^{-3}$ was detected in raw milk of group II cows without electromagnetic impulse treatment. Bacteria of E. coli group were not detected in the milk of cows of both groups, which was exposed to the electro-magnetic impulses generator. When with the device treatment, the quantity of yeast and mold fungi decreased 9 or more times.

When the milk-raw material is processed by an electromagnetic field, an inactivating, there arises an opportunity of suppressing effect on the cell control system both directly by the field and by free electrons formed in the cell due to a strong field presence. The genetic material of the microbial cell is represented by DNA. A DNA molecule carries a lot of negative charges. After the action of the electromagnetic field, free electrons, interacting with charges, suppress the synthesis of DNA and, thereby, stop the cell division $[4 ; 5]$.

\section{Conclusions}

The milk of the cows of both experimental groups met the requirements established by the Technical Regulations of the CU "On Safety of Milk and Dairy Products" (TR TS 033/2013), the Technical Regulations of the CU "On Food Safety" (TR TS 021/2011) and GOST 31449-2013 "Raw cow's milk. Specifications", and was assigned to the highest grade. Milk was characterized by high physico-chemical and technological parameters during all seasons of the year, and met the requirements for raw milk used for the dairy products manufacturing.

Changes in the quantitative composition of the sanitary-indicative microorganisms of raw milk depend both on the way the cows are kept and milked, and on the season of the year. For all seasons the highest microbial population was observed at the group II with tied housing. For both methods of housing, the highest bacterial content was observed in summer. 
The electromagnetic pulse impact on the development of different bacterial groups was detected. The improvement of methods affecting the microbiological parameters of cow milk can be based on the use of an electromagnetic pulse generator to improve the sanitary and hygienic qualities of raw materials intended for the production of dairy products.

\section{References}

[1] Technical Regulations of the CU (TR TS 021/2011) "On Food Safety" (In Russian).

[2] Technical Regulations of the CU (TR TS 033/2013) "On Safety of Milk and Dairy Products" (In Russian).

[3] Sazhinov YU. G. Influence of magnetic field on development of some species of lactic microorganisms. Tezisy` doklada 24 mezhdunarodnogo Molochnogo kongressa (Theses of the report 24 international Dairy congresses). Avstraliya, Melburg, 1994. 227 p. (In Russian).

[4] Charykov V. I. Analysis of electrophysical methods of pasteurization of milk. Prioritetny`e napravleniya razvitiya e`nergetiki v APK: Materialy` I Vserossijskoj nauchno-prakticheskoj konferencii, sentyabr` 2017 (The priority directions of development of power in agrarian and industrial complex: Materials I of the All-Russian scientific and practical conference, September 2017). Kurgan, Kurganskaya GSKHA Publ., 2017, pp. 34-38 (In Russian).

[5] Strašák L., Vetterl V., Šmarda J. Effects of low-frequency magnetic fields on bacteria Escherichia coli. Bioelectrochemistry, 2002. Vol. 55, pp. 161-164.

[6] Hassen H.B., Elaoud A., Trabelsi I. Influence of the magnetic fields on some characteristics of raw milk. International Journal of Advance Industrial Engineering, 2017. Vol.5, No. 4, pp. 200-204.

[7] GOST 13928-84 "Stored up milk and cream. Acceptance rules, methods of sampling and preparation of samples for testing (with change №1)" (in Russian).

[8] GOST 31449-2013 "Raw cow's milk. Specifications" (in Russian). 